\title{
Glaciological investigations in connection with hydropower, South Greenland
}

\section{Poul Clement}

The glaciological investigations in South Greenland, started in the Johan Dahl Land area in 1977, were continued during the field season of 1981. Most of the work was concentrated on the Nordbogletscher, an outlet from the Inland Ice. Nordbogletscher terminates in the lake Nordbosø (660 $\mathrm{m}$ above sea level) which has been proposed as a reservoir for a hydroelectric project in the Nordbosø basin (GTO, 1980). The Nordbogletscher with an area of $208 \mathrm{~km}^{2}$ covers 68 per cent of the basin area $\left(308 \mathrm{~km}^{2}\right)$ and is the most important water source. Several small local glaciers with a total area of $5 \mathrm{~km}^{2}$ are also situated inside the basin. The total glacier cover of the Nordbosø basin thus amounts to 69 per cent. An understanding of the glacier dynamics and measurements of the mass balance are essential for the whole hydropower project.

In addition to the work in Johan Dahl Land, mass balance measurements were carried out at Narssaq Bræ, a local glacier $10 \mathrm{~km}$ north-west of Narssaq town. Proposals for using the meltwater from the glacier for a local hydropower project have been made (GTO, 1980).

\section{Mass balance of Nordbogletscher 1980-81}

The winter balance was measured at the end of May in snowpits, and by depth soundings at stakes scattered over the whole glacier area (fig. 32). The glacier was entirely covered by snow. All the stakes above $1200 \mathrm{~m}$ elevation disappeared during the winter, probably having been broken down by strong wind or icing, and new stakes were established. The snow density measured in fourteen pits from the front of the glacier right up to the top was very uniform with a value of $0.44 \pm 0.04 \mathrm{~g} / \mathrm{cm}^{3}$. The total winter balance was calculated to be $+148 \times 10^{6} \mathrm{~m}^{3}$ of water corresponding to a mean specific winter balance of $+0.71 \mathrm{~m}$ of water equivalent (Table 6 and fig. 33).

The summer balance was determined in the middle of September at stakes drilled into the glacier (fig. 32). The glacier surface at that time was composed of exposed glacier ice up to about $1200 \mathrm{~m}$ elevation where superimposed ice took over. Above $1500 \mathrm{~m}$ elevation the surface was composed of very hard and iced snow cover merging into sastrugi at the top of the glacier. The total summer balance was calculated to be $-199 \times 10^{6} \mathrm{~m}^{3}$ of water (Table 6).

The net balance for $1980-81$ is $-51 \times 10^{6} \mathrm{~m}^{3}$ of water with a mean specific value of -0.25 $\mathrm{m}$ of water equivalent (Table 6). The glacier has thus decreased in volume and an extra amount of water has been delivered to the Nordbosø basin compared with the runoff from glacier-free basins. Compared with last year's results (Clement, 1981) the net balance is about the same, while the winter balance is higher and the summer balance is lower.

A major problem in connection with the mass balance studies on Nordbogletscher is posed by the inadequate maps of the Inland Ice available and the absence of knowledge about the subglacial topography. The area of Nordbogletscher is based on topographic map sheets of 1:250000 only (fig. 32). The subglacial topography which is thought to have caused the diversion of the ice streams is unknown. We do not know the internal or subglacial routes 




Fig. 32. Position of stakes on Nordbogletscher, Johan Dahl Land, South Greenland. Also shown the local glacier at Valhaltinde.

taken by water percolating down from the glacier surface. Comparing the summer balance with the measured runoff from Nordbosø (GTO, personal communication) one finds that the runoff is less than the summer balance. It shows that the internal and/or subglacial water routes probably do not follow the topographic divides. A solution to the problem is to make radio-echo soundings on the glacier surface in combination with discharge measurements from the adjacent glacier (Nordgletscher).

\section{Mass balance of local glaciers}

Better maps are available for the two local glaciers studied, Narssaq Bræ and the glacier at Valhaltinde, and the glacier areas are relatively well defined.

The glacier at Valhaltinde is one of the local glaciers in the Johan Dahl Land area and the Nordbosø basin (fig. 32). The glacier is of a mixed type between a small ice cap and a valley glacier and occupies the northern slopes of the Valhaltinde peak ( $1650 \mathrm{~m}$ above sea level). Three years of mass balance data have been collected; the results from 1980-81 are shown in Table 7. 


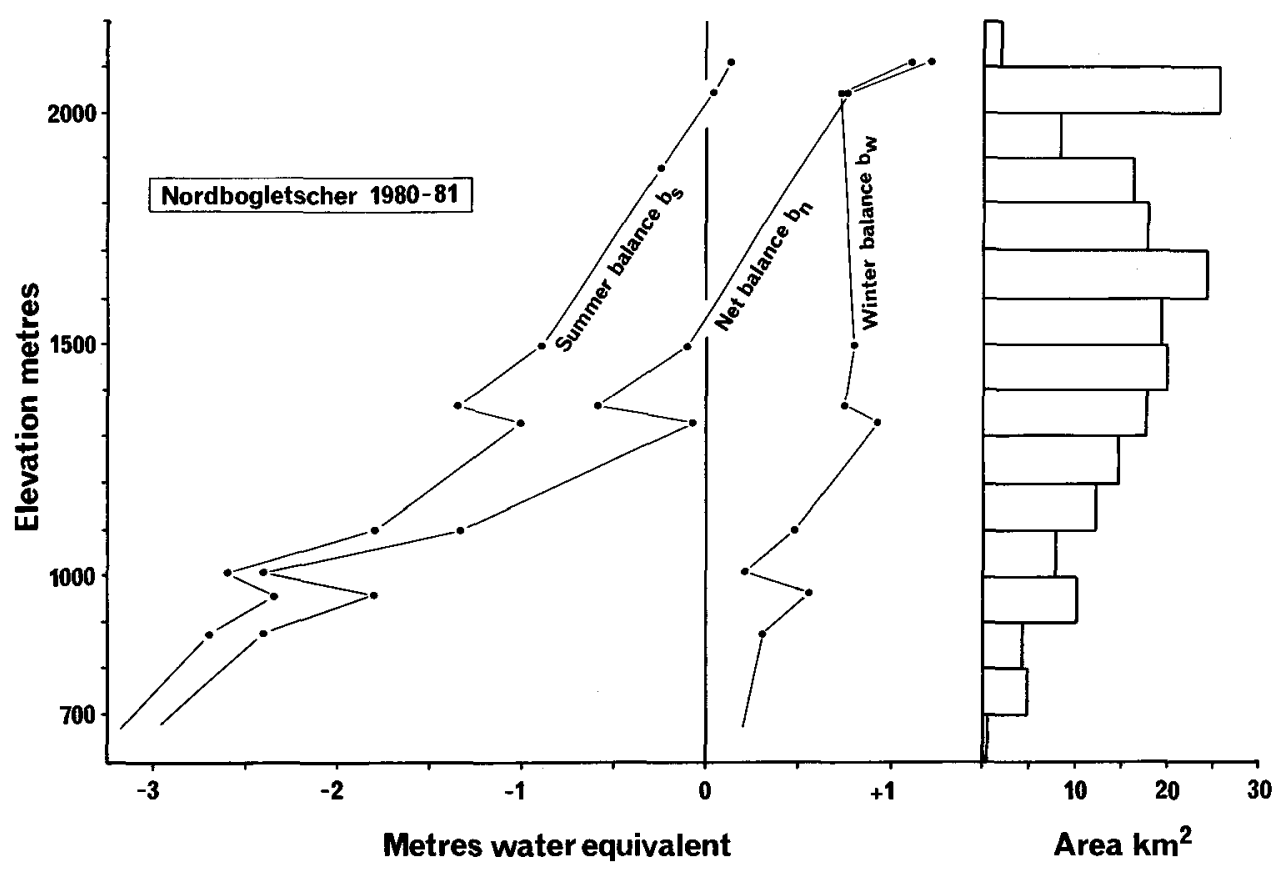

Fig. 33. Winter, summer and net balance in relation to the elevation and area distribution. Nordbogletscher 1980-1981.

At Narssaq Bræ, ten stakes were drilled into the glacier at the end of May in order to determine the winter balance. The summer balance was measured at the stakes on the 18th of September. The results show that Narssaq Bræ has to be divided into two glaciers because of differences in exposure at the two cirque basins occupied by the glacier. The overall result is shown in Table 7.

As Table 7 shows, the net balance of all the glaciers studied was negative. Further the table demonstrates that the mass exchange decreases as one goes from the coast region to the Inland Ice sector, while the elevation of the equilibrium line increases.

\section{Other investigations}

On the tongue of Nordbogletscher at an elevation of $850 \mathrm{~m}$ above sea level detailed ablation measurements were made during the summer months. The ablation varies according to weather conditions, with temperature and wind as the main controlling factors. The highest daily ablation was measured on the 17 th of July in connection with a föhn situation and found to be $117 \mathrm{~mm}$ of water equivalent. The mean daily ablation in June was $34 \mathrm{~mm}$, in July $42 \mathrm{~mm}$ and in August $18 \mathrm{~mm}$.

The velocity at the stakes on Nordbogletscher at elevations below $1200 \mathrm{~m}$ altitude was measured with a theodolite from fixed points established on the ground. The yearly velocity on the central part of the glacier is $90-100 \mathrm{~m} / \mathrm{y}$. 
Table 6. Winter, summer and net balance in relation to the elevation and area distribution. Nordbogletscher 1980-1981

\begin{tabular}{lcccccccc}
\hline Height & Area & \multicolumn{2}{c}{ winter balance } & \multicolumn{2}{c}{ Summer balance } & \multicolumn{2}{c}{ Net balance } \\
m. a.s.1. & $\mathrm{km}^{2}$ & $\mathrm{~B}_{\mathrm{w}}$ & $\mathrm{b}_{\mathrm{w}}$ & $\mathrm{B}_{\mathrm{s}}$ & $\mathrm{b}_{\mathrm{s}}$ & $\mathrm{B}_{\mathrm{n}}$ & $\mathrm{b}_{\mathrm{n}}$ \\
& & ${ }^{6} 0^{6} \mathrm{~m}^{3}$ & $\mathrm{~m}$ & $10^{6} \mathrm{~m}^{3}$ & $\mathrm{~m}$ & $10^{6} \mathrm{~m}^{3}$ & $\mathrm{~m}$ \\
\hline $2200-2100$ & 1.97 & 2.19 & 1.11 & 0.24 & 0.12 & 2.42 & 1.23 \\
$2100-2000$ & 26.11 & 19.06 & 0.73 & 0.26 & 0.01 & 19.32 & 0.74 \\
$2000-1900$ & 8.51 & 6.38 & 0.75 & -1.02 & -0.12 & 5.36 & 0.63 \\
$1900-1800$ & 16.47 & 12.35 & 0.75 & -4.78 & -0.29 & 7.58 & 0.46 \\
$1800-1700$ & 17.99 & 13.85 & 0.77 & -8.46 & -0.47 & 5.40 & 0.30 \\
$1700-1600$ & 24.46 & 19.08 & 0.78 & -15.41 & -0.63 & 3.67 & 0.15 \\
$1600-1500$ & 19.62 & 15.30 & 0.78 & -15.89 & -0.81 & -0.59 & -0.03 \\
$1500-1400$ & 19.86 & 15.49 & 0.78 & -21.05 & -1.06 & -5.56 & -0.28 \\
$1400-1300$ & 17.69 & 14.86 & 0.84 & -21.23 & -1.20 & -6.37 & -0.36 \\
$1300-1200$ & 14.45 & 11.13 & 0.77 & -18.50 & -1.28 & -7.37 & -0.51 \\
$1200-1100$ & 12.25 & 6.98 & 0.57 & -19.97 & -1.63 & -12.99 & -1.06 \\
$1100-1000$ & 7.97 & 2.79 & 0.35 & -17.93 & -2.25 & -15.14 & -1.90 \\
$1000-900$ & 10.58 & 5.50 & 0.52 & -25.29 & -2.39 & -19.78 & -1.87 \\
$900-800$ & 4.84 & 1.36 & 0.28 & -13.07 & -2.70 & -11.71 & -2.42 \\
$800-700$ & 5.22 & 1.20 & 0.23 & -15.56 & -2.98 & -14.36 & -2.75 \\
$700-600$ & 0.32 & 0.06 & 0.20 & -1.01 & -3.17 & -0.95 & -2.97 \\
\hline $2200-600$ & 208.30 & 147.58 & 0.71 & -198.67 & -0.95 & -51.07 & -0.25 \\
\hline
\end{tabular}

Meteorological observations were continued from two weather stations, one at base camp beside the glacier (fig. 32) and one at the same altitude ( $850 \mathrm{~m}$ above sea level) on the glacier itself. Beside the weather station on the glacier surface, an energy-balance station measuring net radiation, wind and temperature profiles was installed by personnel from the Laboratoriet for Fysisk Geografi, Århus University. At the base camp, the measurements included temperature, humidity, wind, evaporation, sunshine, precipitation and shortwave radiation.

Near the base camp is an ice-dammed lake which taps every year under the Nordbogletscher to Nordbosø. Water-level variations and inflow to the lake were continuously recorded in order to estimate the volumes of water involved in the tapping. The lake is filled up at the beginning of the ablation period; the critical level is reached about the first of July when the water level has risen $40 \mathrm{~m}$ from the bottom. The tapping of the lake is relatively slow and takes about two months. Preliminary results show that 25 per cent of the annual runoff from Nordbosø is drained through this lake. 
Table 7. General information on glaciers studied in South Greenland, 1981, together with the collected mass balance data for the budget year 1980-1981

\begin{tabular}{|c|c|c|c|}
\hline Glacier name & Narssaq Brw & Valhal tinde glacier & Nordbogletscher \\
\hline Glacier code no & $1 \mathrm{AG} 01001$ & $1 \mathrm{AGO} 5008-9$ & $1 \mathrm{ACO} 05001$ \\
\hline Glacier position & $60^{\circ} 58^{\prime} \mathrm{N}, 45^{\circ} 58^{\prime} \mathrm{W}$ & $61^{\circ} 26^{\prime} \mathrm{N}, 45^{\circ} 21^{\prime} \mathrm{W}$ & $61^{\circ} 25^{\prime} \mathrm{N}, 45^{\circ} 23^{\prime} \mathrm{W}$ \\
\hline Glacier type & local glacier & local glacier & outlet glacier \\
\hline Glacier area, $\mathrm{km}^{2}$ & 1.4 & 1.9 & 208.3 \\
\hline Elevation of front, ma.s.l. & 900 & 1080 & 660 \\
\hline Elevation of highest point, $\mathrm{ma} \cdot \mathrm{s.l}$. & 1275 & 1630 & 2140 \\
\hline Distance from coast, $\mathrm{km}$ & 45 & 110 & $100-140$ \\
\hline Number of stakes inserted in glacier & 10 & 7 & 38 \\
\hline Winter balance, $B_{w}, 10^{6} \mathrm{~m}^{3}$ & 2.26 & 1.07 & $147 \cdot 58$ \\
\hline Mean specific winter balance, $b_{w}$, m & 1.58 & 0.57 & 0.71 \\
\hline Summer balance, $B_{s}, 10^{6} \mathrm{~m}^{3}$ & -2.78 & -2.02 & -198.67 \\
\hline Mean specific summer balance, $b_{s}, m$ & -1.94 & -1.07 & -0.95 \\
\hline Net balance, $B_{n}, 10^{6} \mathrm{~m}^{3}$ & -0.52 & -0.95 & -51.07 \\
\hline Mean specific net balance, $b_{n}, m$ & -0.36 & -0.50 & -0.25 \\
\hline Equilibrium line, m a.s.l. & 1125 & 1440 & 1560 \\
\hline
\end{tabular}

The outlet glaciers in the Johan Dahl Land area are in general advancing. The glaciers (Eqalorutsit kangigdlit sermiat, Nordbogletscher and Nordgletscher) have been growing for most of this century; they are all characterized by missing trimline zones and the lack of older moraines and their present ice fronts seem to be the furthest advanced in historic times. A cairn system has been established at the margin of Nordbogletscher and at the front of Nordgletscher. The latter has advanced $50 \mathrm{~m}$ since last year and in total $450 \mathrm{~m}$ since 1969. The reason for the advance is unknown but seems to be dynamic rather that climatic. In view of the hydropower project, the advance of Nordbogletscher into the proposed reservoir could be a serious problem.

\section{References}

Clement, P. 1981: Glaciological investigations in Johan Dahl Land 1980, South Greenland. Rapp. Grønlands geol. Unders. 105, 62-64.

GTO 1980: Vandkraft omkring Tunugdliarfik. Rapp. Grønlands Tekniske Organisation, 48 pp. 